\title{
Bisphosphonates as treatment of secondary osteoporosis in children: a case series
}

\author{
Frida Soesanti ${ }^{1 *}$, Fitria Mayasari², Aman B Pulungan ${ }^{1}$ \\ From 8th APPES Biennial Scientific Meeting \\ Darwin, Australia. 29 October - 1 November 2014
}

\section{Background}

Secondary osteoporosis due to chronic disease is a major pediatric health concern and has certain unique diagnostic with various clinical challenges. Bisphosphonates has been used in small numbers of pediatric patients to treat secondary osteoporosis resulted in significantly fewer fractures and improved mobility.

\section{Objective}

To present case series of secondary osteoporosis due to chronic disease treated with biphosphonate.

\section{Case Series}

We included 6 patients (2 boys, 4 girls), 7-15 years of age with secondary osteoporosis who were treated with biphosphonate. Two patients were diagnosed acute lymphoblastic leukemia, two patients with systemic lupus erythematosus and others with juvenile rheumatoid arthritis. Two patients received methotrexate and dexamethasone; one patient was treated with methotrexate and prednisone; two patients with methylprednisolone; and rest with only methotrexate. Four of them suffered back pain due to trauma and from radiographic examination showed multiple compression fracture on the vertebrae. Lumbal BMD Z-score was ranging from -2.8 to -5.1 in patients who had fracture, while in patients without fracture -2.6 to -3.1 . We used zoledronic acid $0.05 \mathrm{mg} / \mathrm{kgBW}$. Two patients already received pamidronate as previous treatment. In 6 - 12 months of followup, there were evidence of reduced pain, improved mobility and BMD Z-score, also no evidence of new fractures in radiographic evaluation.

'Pediatric Endocrinology Division, Faculty of Medicine, University of Indonesia-Cipto Mangunkusumo hospital, Jakarta, Indonesia Full list of author information is available at the end of the article

\section{Conclusion}

Bisphosphonates appears to be safe and effective as treatment for children with secondary osteoporosis.

\section{Authors' details}

'Pediatric Endocrinology Division, Faculty of Medicine, University of Indonesia-Cipto Mangunkusumo hospital, Jakarta, Indonesia. ${ }^{2}$ Pediatrics Departement, University of Indonesia, Jakarta, Indonesia.

Published: 28 April 2015

doi:10.1186/1687-9856-2015-S1-P67

Cite this article as: Soesanti et al:: Bisphosphonates as treatment of secondary osteoporosis in children: a case series. International Journal of Pediatric Endocrinology 2015 2015(Suppl 1):P67.
Submit your next manuscript to BioMed Central and take full advantage of:

- Convenient online submission

- Thorough peer review

- No space constraints or color figure charges

- Immediate publication on acceptance

- Inclusion in PubMed, CAS, Scopus and Google Scholar

- Research which is freely available for redistribution

Submit your manuscript at www.biomedcentral.com/submit
() Biomed Central 